\title{
Genetic control of the development of the haploid generation in Oenothera
}

\author{
CORNELIA HARTE \\ Institut für Entwicklungsphysiologie, Universität zu Köln, Gyrhofstr. 17, \\ D 5000 Köln 41, BRD
}

(Received: September 26, 1983. Accepted: November 22, 1983)

\begin{abstract}
The haploid generation of higher plants has to be considered in its own individuality. Special experimental designs are needed to investigate the developmental processes of the male and female gametophytes between meiosis and fertilization. Experiments on Oenothera demonstrate the existence of genes, which action can be described as influencing the competition between meiospores or between gametophytes, or as interaction between different individuals, the gametophytic-gametophytic and gametophytic-sporophytic incompatibility. The development of the haploid generation is regulated by genes. Some of these genes are active only in this phase of the life cycle.
\end{abstract}

Key words: Oenothera, gametophyte, gene action, competition, fertilization, incompatibility.

The generation cycle of plants with a diploid sporophyte and a haploid gametophyte is well known, but, in investigations on the development of these plants, the importance of the haploid generation is often neglected. The embryo sac is considered as a part of the ovary without its own individuality and the pollen tube is taken as a structure necessary only to carry the male gametes. Sometimes even the difference between the carrying structure and the gametes is overlooked. A haploid cell has some genetic similarities with the plant on which the meiotic mother cell was formed. It can contain only alleles that were present in the mother plant, but is does not contain all the alleles, only one-half of them. The haploid spore and the gametophyte coming forth from it is not just a part of the mother plant, but an individual that is genetically different from the diploid from whom it originated and has its own developmental history. 
It is acknowledged on the other hand that the development of an individual is regulated by genes which come into action at certain stages. From these statements several questions arise: Is the development of the haploid spores into gametophytes after meiosis completely regulated by the mother plant or has in fact the gametophyte its own genetically controlled regulation system for its development? Are there genes which are specially designed to regulate the development of the gametophyte and which are inactive in the diploid phase? At first the assumption of gametophytic genes sounds rather odd, but there must be many genes which are active only during a short part of the life span or at a certain stage of a few cells only, so why not only in the haploid phase? The development of the haploid generation, the embryo sac and pollen tubes, has a great importance for the propagation, the developmental biology and the genetics of higher plants. So we are entitled to have a special interest in the gametophytes.

The Mendelian laws of inheritance are based on the following assumptions (Fig. 1): 1) In a heterozygote $a_{x} / a_{y}$ the gametes with the alleles $a_{x}$ or $a_{y}$ respectively are produced with the same frequency. The probability of fertilization of a gamete is independent of the genetic constitution of the individual on which it was produced, or in other words, all gametes with the allel $a_{x}$ have the same probability of fertilization, independent of their origin from a homozygote $a_{x} / a_{x}$ or from a heterozygote $a_{y} / a_{x}$. 2) In higher plants, the additional assumption is made that the genetic constitution of the two sporophytes which are involved does not influence the development of the gametophytes, and, that the gametes which will fertilize one another, are taken at random out of the poll of gametes, irrespective of their origin and their genetic constitution. These assumptions are the basis of population genetics of higher organisms.

\section{1. frequency of gametes of heterozygote$$
\mathrm{h}\left(\mathrm{a}_{\mathrm{x}}\right)=\mathbf{h}\left(\mathrm{a}_{\mathrm{y}}\right)=0.5
$$

2. probability of fertilization independent of allele in gamete

$$
\mathbf{P}\left(\mathbf{f} \mid \mathbf{a}_{\mathbf{x}}\right)=\mathbf{P}\left(\mathbf{f} \mid \mathbf{a}_{\mathrm{y}}\right)
$$

\section{3. probability of fertilization independent of parent $\mathbf{P}\left(\mathbf{f a}_{\mathbf{x}} \mid \mathbf{a}_{\mathrm{x}} \mathbf{a}_{\mathrm{x}}\right)=\mathbf{P}\left(\mathbf{f} \mathbf{a}_{\mathrm{x}} \mid \mathbf{a}_{\mathrm{x}} \mathbf{a}_{\mathrm{y}}\right)$ \\ 4. probability of fertilization independent of partner $\left.\mathbf{P f} \mathbf{a}_{\mathrm{x}} \mid \mathbf{a}_{\mathrm{x}}\right)=\mathbf{P}\left(\mathbf{f} \mathbf{a}_{\mathrm{x}} \mid \mathbf{a}_{\mathrm{y}}\right)$}

Fig. 1. Assumptions on which the expectation for segregation ratios in Mendelian inheritance is based

Only the first assumption is justified by the mechanism of meiosis. A meiocyte of a diploid heterozygous individual $a_{x} / a_{y}$ develops into 4 haploid cells in which the two alleles $a_{x}$ and $a_{y}$ have the relative frequency of exactly $h=0.5$. In random selection of a haploid cell, the 
probability that this cell will contain a certain allel $a_{i}$ is $p\left(a_{i}\right)=0.5$, where $i \varepsilon\{x, y\}$. All of the other assumptions are very convenient, but there is no reasor to take them for granted in every case without proof. Only if during the development of the haploid cells into gametes, which can go on directly or by means of the haploid generation, neither propagation nor selection occurs, will this same probability hold for the fertilizing gametes.

Already during the first years of genetic research, deviations of segregation numbers from those expected on the grounds of Mendelian laws were observed in cases where was no doubt about the monofactorial basis of a character and the heterozygosity of the parents (review: H a r t e 1967, 1975). If in controlled progenies significant deviations from this expectation occur, and if in addition a selection process in the diplophase by death of individuals between the origin of the zygotes and the time of observation can be exluded, then selection in the haplophase remains as the only interpretation of this result. There are three possibilities for such a selection process: incompatibility, selective fertilization and competition between cells in the haploid phase. This can involve the spores, the gametophyte or the gametes.

The term "incompatibility" in the context of biology of fertilization means a disturbance in the cooperation between the pollen tube and those tissues of the flower that are important for the growth of pollen tubes and fertilization. This leads to the inability of the pollen tubes to grow through the style and prevents them from delivering the gametes to the embryo sac.

The term "selective fertilization" covers all processes which lead to the situation that the relative frequency with which the expected diploid genotypes are formed by fertilization, deviates from the probability with which they should occur by random meeting of the two cells from the pools of male and female gametes. This means that the probability with which a random meeting of the two gametes will lead to fertilization depends on the genetic constitution of these two gametes.

The term "competition of spores or gameltes" means, on the contrary, that in case two gametes meet, the process of fertilization occurs at random, but that the probability with which a gamete of a given genotype will meet another gamete does not correspond to the relative frequency of this genotype in the population of spores after meiosis (Figs. 2, 3). This difference between the relative frequency of a genotype in a heterogenous population of gametes and the probability of fertilization will arise when the genome contains genes which influence any characters of the gametes or gametophytes which are important for the process of fertilization. Then the chance of a cell to be involved in fertilization is correlated with the gene-dependent expression of the character 
under consideration. A formal description of the phenomena is given in the figures. The genus Oenothera gives examples for all three cases.

$$
\begin{aligned}
& \mathbf{P}\left(a_{1}\right)=\text { probability of a gamete with the allele } a_{i} \text { in the population } \\
& \mathbf{P}^{\prime}\left(a_{1}\right)=\text { probability of a gamete with the allele } a_{i} \text { at fertilization } \\
& \text { Mendelian population } \\
& \mathbf{P}\left(a_{i}\right)=\mathbf{P}^{\prime}\left(a_{1}\right) \\
& \text { competitive gametes } \\
& \mathbf{P}\left(a_{1}\right) \neq \mathbf{P}^{\prime}\left(a_{1}\right) \\
& \text { and } \mathbf{P}\left(a_{x}\right)<\mathbf{P}^{\prime}\left(a_{x}\right) \text { if } \mathbf{P}\left(a_{y}\right)>\mathbf{P}^{\prime}\left(a_{y}\right)
\end{aligned}
$$

Fig. 2. Probability $\mathrm{P}^{\prime}$ for the occurence of the alleles $a_{x}$ and $a_{y}$ in the population of gametes at the time of fertilization

$$
\begin{gathered}
\left(a_{x} \mid a_{x} a_{x}\right)=\text { gamete with allele } a_{x} \text { from diploid homozygote } a_{x} a_{x} \\
\left(a_{x} \mid a_{x} a_{y}\right)=\text { gamete with allele } a_{x} \text { from diploid heterozygote } a_{x} a_{y} \\
P\left(a_{x}\right)=\text { probability of fertilization of a gamete with allele } a_{x} \\
\text { Mendelian population: } \\
\mathbf{P}\left(a_{x} \mid a_{x} a_{x}\right)=P\left(a_{x} \mid a_{x} a_{y}\right) \\
\text { parent-determined competition: } \\
\mathbf{P}\left(a_{x} \mid a_{x} a_{x}\right)=P\left(a_{x} \mid a_{x} a_{y}\right)
\end{gathered}
$$

Fig. 3. Competition between gametes dependent on diploid parent

Let us first consider incompatibility. E m e r s on $(1939,1940)$ found in Oenothera organensis a population of plants that did not set seed after selfing. The genetical analysis carries the hypothesis that a gene exists with many alleles that influences the development of the pollen tubes. A pollen tube with the allele $s_{i}$ cannot grow in a style whose cells contain the same allel, irrespective of the other allel that is present in the diploid. There must be an interaction between a gene product in the style and another in the pollen tube, made by the same allele so that the result is the inhibition of the growth of the pollen tube.

From this several questions arise: There are multiple alleles at the $S$-locus. Is there an extremely high mutation rate, or a selection process in favour of multiple alleles? At which stage of development will the gene in the pollen be active? Is the reaction already fixed when the pollen germinates or will the $S$-allele become active anly as reaction to the gene product or are there two, a different on in the style and in the pollen tube? Experiments on mutagenesis by Lew is $(1948,1949$, 1951) gave the answer to all of these questions. The mutation rate after irradiation was not extraordinarily high. When mature pollen was irradiated, mutations did occur, but the mutation was ineffective for the pollen in which it occured. Only in the next generation was the change of reaction type found. This means that the reaction of the pollen was determined before the mutation occured. After irradiation of the young 
pollen immediately after meiosis, however, the pollen with a mutated allele could grow in the style of a flower with the original allele, where it should have shown the incompatibility reaction. The conclusion is, that the $S$-gene is active shortly after meiosis during the development of the microspore into the pollen grain. When the gene product is present, a mutation cannot bring about a change in the behaviour of the pollen tube developing later from the pollen grain. The investigations of the next generations with mutations of the $S$-locus showed some peculiarities of the new alleles. In some of them only the pollen reaction was changed, but if they were present in the style, the new alleles behaved like the old one, from which they originated. In other cases (Prunus avium, L e$\mathrm{w}$ is and $\mathrm{Crow}$ e 1954) the reaction was changed when the new allel was present in the style. It did not disturb the growth of pollen tubes with the original allele but, when present in the pollen, it could recognize the original one in the style (Table 1). The interpretation is, that the $S$-gene is a complex locus and consists at least of two closely linked parts, one for the reaction of the style and one for the pollen reaction. In Fiterature such reaction are described as gametophytic incompatibility, but this takes into account only the reaction of the pollen tube, which is seen as being regulated by its own genes. In fact, the reaction depends on the interaction with the diploid cells of the stylar tissue. Therefore it should be called a gametophytic-sporophytic incompatibility system. Similar incompatibility systems as that investigated in Oenothera organensis were found in other sections of the genus Oenothera and can explain some cases of deficiency of genotypes in the progeny ( $\mathrm{S}$ te in e r 1957, 1961a, b).

Table 1

Behaviour of mutated S-alleles

\begin{tabular}{|c|c|c|}
\hline Original allele & Mutated allele & Action \\
\hline \multicolumn{2}{|c|}{$\mathrm{s}_{\mathbf{x}} \searrow \begin{array}{l}\mathrm{s}_{\mathbf{x}}^{\prime} \\
\mathrm{s}_{\mathrm{x}}^{\prime \prime}\end{array}$} & $\begin{array}{l}\text { pollen reaction changed } \\
\text { stylar reaction changed }\end{array}$ \\
\hline \multicolumn{2}{|c|}{ Genetic constitution of } & \multirow{2}{*}{ reaction of pollen tube in style } \\
\hline Pollen tube & style & \\
\hline $\begin{array}{l}\mathrm{s}_{\mathbf{x}}^{\prime} \\
\mathrm{s}_{\mathbf{x}} \\
\mathrm{s}_{\mathbf{x}}^{\prime \prime} \\
\mathrm{s}_{\mathbf{x}} \\
\mathrm{s}_{\mathbf{x}}\end{array}$ & $\begin{array}{l}\mathrm{s}_{\mathbf{x}} \mathrm{s}_{\mathbf{i}} \\
\mathrm{s}_{\mathrm{x}}^{\prime} \mathrm{s}_{1} \\
\mathrm{~s}_{\mathbf{x}} \mathrm{s}_{\mathbf{i}} \\
\mathrm{s}_{\mathbf{x}}^{\prime \prime} \mathrm{s}_{1} \\
\mathrm{~s}_{\mathbf{x}} \mathrm{s}_{\mathbf{1}}\end{array}$ & $\begin{array}{l}\text { growth of pollen tube } \\
\text { inhibition of pollen tube } \\
\text { inhibition of pollen tube } \\
\text { growth of pollen tube } \\
\text { inhibition of pollen tube }\end{array}$ \\
\hline
\end{tabular}

If the pollen tube can pass trough the style, its next problem is to find the egg cells in the ovule. This raises the question if meeting of the gametes is random or if there is a preference for certain combinations 
called selective fertilization. Histological preparations showed that the pollen tube reaches the egg through the micropyle (R e n ner and Preuss-Herzog 1943). It seems as if chemotropism is involved. If the pollen tube is attracted by the ovule, then fertilization should be random in cases of genetic heterogeneity of embryo sacs or pollen. In Oenothera of the section Raimannia, S c h w e m m le $(1949,1953 \mathrm{a}, \mathrm{b})$ and his collaborators investigated the progeny after selfing and crossing of several species (review: $\mathrm{H}$ a u s tein 1967). In this group there were homozygotic species such as Oe. berteriana and Oe. odorata. Both Renner-complexes occured at random in the embryo sac and in the pollen, but never all of the genotypes which were expected were found in the progeny. Some examples are shown in Table 2 . The hybrids were viable. The homozygotes were lethal, but could be found and identified as degenerating embryos or empty seeds.

Table 2

Selective fertilization (data from Schwemmle 1953a, b)

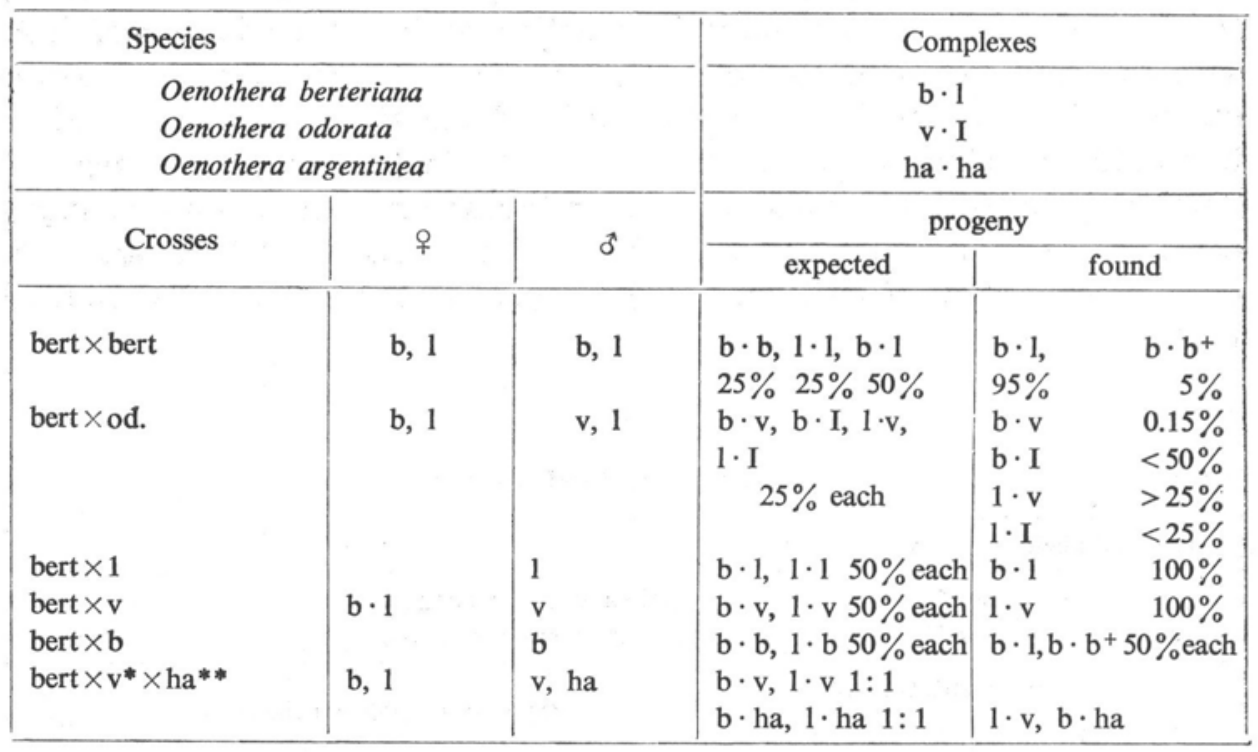

* first fertilization, ** second fertilization.

With some experience it is possible to create hybrids where only pollen with one of the complexes is active, the other lethal or inactive. Crosses with homogenous pollen are then made possible. The results of many experiments show, that there exists a genetically controlled affinity between pollen tubes and embryo sacs. Some hybrids do not occur in crosses where they are expected, because a pollen tube with a certain complex does not enter an embryo sac with the same genetical consitu- 
tion. Double pollinations, where a first batch of pollen brought onto the style had the opportunity of fertilization ad libitum and a second batch of genetically different pollen several hours later had to take the left-overs, confirmed this hypothesis. The results of some of these crossing experiments are given in Table 2.

The conclusion is that a gene exists that is active in the pollen tube and the embryo sac. It is responsible for the chemotropic cooperation between the gametophytes. This encompasses the attraction by the embryo sac and the reaction of the pollen tube as well. There is a high degree of plausibility for the assumption that this involves the production of a chemotropical active substance by the embryo sac which is different according to the genotype and the specific attractability of the pollen tube. The prevention of fertilization by genetical similarity of pollen tube and embryo sac is a special case of incompatibility between the two gametophytes. It is a gametophytic-gametophytic incompatibility system.

Table 3

Genetic constitution of gametes and progeny of Oenothera biennis

\begin{tabular}{|c|c|c|c|}
\hline & & \multicolumn{2}{|c|}{ In egg cells } \\
\hline & Complex & balbicans & rubens \\
\hline ङ & rubens & $\begin{array}{l}\text { vital } \\
\text { embryo }\end{array}$ & $\begin{array}{l}\text { lethal embryo } \\
\text { empty seeds }\end{array}$ \\
\hline ฐ & $\begin{array}{l}\text { balbicans } \\
\text { inactive }\end{array}$ & - & - \\
\hline
\end{tabular}

The deviations of the frequency of genotypes from Mendelian segregation can be brought about by still another process. First R e n n er (1921) found unexpected segregations in Oenothera-progenies and gave the interpretation of competition in the haploid generation specially during the development of the embryo sac. In heterozygotic species of the section Eu-oenothera he found that the two gene-complexes did not occur with the same frequency in the embryo sacs (Table 3). A quantitative look at the problem is only possible by means of experiments which are planed specially for the purpose of investigating competition in the haploid generation. It was necessary to make an experimental design so that the data could not only proove the existence of competition, but would also provide estimates of the causes of variability of the competition in both sexes. The experiments were made possible by the formation of gene-complexes in Oenothera as the result of reciprocal translocations between chromosomes. For investigating the competition in the ovaries, heterogamic species and their hybrids, which all had a high degree of chromosomal catenation, were used. One of the gene-complexes which was inactive in the pollen and was inherited only through the 
eggs, was called the egg-cell-complex. The functioning pollen of such a hybrid was homogenous and contained the other complex, called the pollen-complex. In the cases investigated, the pollen-complex contained a lethal gene which caused the death of the homozygous embryos. After selfpollination in a plant whose genetic constitution was characterized by an egg-cell-complex and a pollen-complex, vital embryos could only develop from embryo sacs with the egg-cell-complex fertilized by the pollen-complex. The eggs which contained the pollen-complex would, after being fertilized by a sperm cell with the same complex, develop lethal embryos which could be detected as empty seeds. We crossed 13 species so that we had 86 species and hybrids. Each egg-cell-complex was combined with several pollen-complexes and vice versa. The flowers of the $F_{1}$ were selfpollinated and the frequency of seeds with viable embryos was determined. A statistical analysis of these frequencies was performed (examples in Table 4) (H a r te 1958a, b, c).

Table 4

Frequency of pollen complexes in egg-cells

\begin{tabular}{|l|c|c|}
\hline \multicolumn{1}{|c|}{ Species } & Complexes & $\begin{array}{c}\% \text { pollen complex } \\
\text { in egg-eclls }\end{array}$ \\
\hline $\begin{array}{l}\text { Oe. biennis } \\
\text { race Hannover } \\
\text { hybrid } \\
\text { strigosa } \\
\text { hybrid }\end{array}$ & balbicans $\cdot$ rubens & $11 \%$ \\
\hline
\end{tabular}

There are two main hypotheses to be tested. First, if the genetic constitution of a megaspore does not have any influence on the chances of development, then both gene-complexes should appear in the fertile embryo sacs of a heterozygote with the same probability of $p=0.5$, and, as a consequence, the same holds for the vital embryos after selfing. A significant deviation from this expectation in the direction of more vital embryos prooves that the megaspores with the egg-cell-complex develop more frequently into an embryo sac than those with the pollen-complex. In this case there must be competition between the megaspores in the tetrad of one meiocyte. The data show that the chance of a megaspore with a certain egg-cell-complex to win this competition is variable and depends on unknown environmental influences which vary between plants and between flowers of one plant during the vegetation period.

In the second hypothesis, the crucial question is, whether strength of the egg-cell-complex, measured as its success to appear in the embryo 
sacs of a heterozygote, depends only on its own genes, irrespective of the other complex with which it is combined. The alternative hypothesis is, whether the primary factor is the inability of the megaspores containing the pollen-complex to develop into an embryo sac. In this case the remaining megaspores with the egg-cell-complex only have to take the open places, as was suggested by Renner (1940). In several cases it could be prooved that a change in competition behaviour of pollen-complexes, which passed through the embryo sac into the next generation, was accompanied by other genetic changes (Oehlkers and $\mathrm{Harte}$ 1943).

According to the first hypothesis, the frequency of the vital embryos should depend only on the egg-cell-complex of a hybrid and be independent of the pollen complex with which it is combined. From the alternative of the hypothesis it follows that mean and variances of this frequency should be the same in all hylbrids with the same pollen-complex, irrespective of the combination with different egg-cell-complexes. The results of the analysis of the data is that the pollen-complexes differ in their strength, but the megaspores containing the egg-cell-complex do not take over passively the open places left by non-developing competitors. They clearly influence the result of the competition. An interaction exists between the two complexes in a heterozygote. The outcome of the competition in a new hybrid cannot be predicted by the knowledge of their behaviour in combination with other complexes.

This can be illustrated by an example (Tables 3,4$)$. The pollen-complex rubens will apear in the embryo sac of its natural species, Oenothera biennis, in appr. $11 \%$. In the combination with the complex excellens of Oe. chicaginensis, this frequency is $30 \%$. The pollen-complex stringens of Oe. strigosa appears in the species in less than $2 \%$ of the eggs, but in the combination balbicans . stringens the frequency of lethal embryos varied in different years between $5 \%$ and $77 \%$.

The genetic factors which are involved in the megaspore competition cannot act directly, but they determine the range of variability in which the hybrid can react to modifying influences. This range is very narrow in the heterozygotic species and extremely large in some artificial hybrids. The complexes of a species are in balance in relation to their competitive ability. In species hybrids such a balance does not exist. From this it follows that the genetic influence on the development of the megaspores and the embryo sac cannot be a simple one, and that a polygenic background is the most plausible explanation.

In the experiments described untill now, the complexes were taken as units. The lethal factors, for which it is known that crossing-over against the translocation points of the chromosomes is negligible, were used as markers for the whole complex. For investigations on details of the genetic basis, other hybrids had to be used, where the catenation of 
the chromosomes is less, so that the complexes fall apart in chromosome-groups and bivalents during meiosis. Some of these groups can be genetically identified by markers which influence characters of the sporophyte. These loci can be used to find details about the genetic basis of competition between the spores ( $\mathrm{H}$ a r te 1948, 1961, 1969a, b, c).

The first linkage group corresponding to the chromosome ends number 1 to 4 contains the loci $s$ for flower colour and de for form of the tip of the inflorescence made by the bracts. In the hybrids between hookeri and flavens, these chromosomes form a ring of four, so that the translocation point $\mathrm{T}$ can be used as an additional marker. In both complexes there are no lethal factors located in these chromosomes. All three loci show significant deviations from expected segregation ratios. First it was assumed that the alleles of the gene $s$ influence the development of the gematophytes in addition to their action in the sporophyte. With an appropriate experimental design it was possible to test and reject this hypothesis. The species Oe. hookeri and suaveolens are both available in races with yellow and sulfur flowers, corresponding to the alleles $s^{+}$and $s$ respectively (Table 5). So these two alleles can be introduced into the hybrids in different combinations with the two complexes hhookeri and flavens. The hybrids were backcrossed to Oe. hookeri sulfurea, homozygous for $s$ and $d e$, and other appropriate partners (Table 6). The result was in all cases that, irrespective of the combination in which the alleles and complexes were introduced into the hybrid, the alleles of hookeri were significantly over-represented in the progeny. A similar result was found in backcrosses with the pollen of the same hybrids.

\section{Table 5}

Results of test crosses of ${ }^{\mathrm{h}}$ hookeri - flavens-heterozygotes with double recessive gametes

\begin{tabular}{|c|c|}
\hline Heterozygote & $\begin{array}{l}\text { Progeny } \\
\text { from back } \\
\text { crosses ex- } \\
\text { cess from } \\
\text { gametes }\end{array}$ \\
\hline 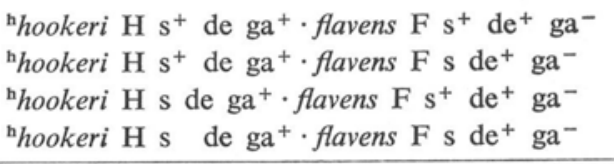 & $\begin{array}{l}\mathrm{H} \text { de } \\
\mathrm{H} \mathrm{s}^{+} \text {de } \\
\mathrm{H} \mathrm{s} \mathrm{de} \\
\mathrm{H} \mathrm{de}\end{array}$ \\
\hline
\end{tabular}

These experiments lead to the interpretation that in the first chromosome group, which cytologically corresponds to a translocation figure of 4 chromosomes, a gene ga must be present that influences the development of the gametophytes. The allele $g a^{+}$lies in one of the chromo- 
Table 6

Test crosses with hybrid Oenothera ${ }^{\text {bhooker }} \cdot$ flavens

\begin{tabular}{|c|c|c|c|c|c|}
\hline Hybrid & Backcross parent & Complex & $\begin{array}{c}\text { Test for } \\
\text { competition } \\
\text { in }\end{array}$ & $\begin{array}{l}\text { Competition } \\
\text { gene }\end{array}$ & Test loci \\
\hline$\sigma^{*}$ & $\begin{array}{l}\text { 우 Oe. hookeri } \\
\text { 우 Oe. hookeri sulfurea }\end{array}$ & $\begin{array}{l}{ }^{\mathrm{h}} \text { hookeri } \mathrm{s}^{+} \\
{ }^{\mathrm{h}} \text { hookeri s }\end{array}$ & pollen & ga (m) & $\begin{array}{l}T, \text { de } \\
T, s, \text { de }\end{array}$ \\
\hline 우 & $\begin{array}{l}\text { o } \text { Oe. hookeri } \\
\text { o Oe. hookeri sulfurea } \\
\text { o Oe. suaveolens } \\
\text { ¿ Oe. } \text { suaveolens sulfurea }\end{array}$ & $\begin{array}{l}{ }^{\mathrm{h}} \text { hookeri } \mathrm{s}^{+} \\
\text {"hookeri } \mathrm{s} \\
\text { flavens } \mathrm{s}^{+} \\
\text {flavens } \mathrm{s}\end{array}$ & embryo sac & ga (f) & $\begin{array}{l}T, \text { de } \\
T, s \text {, de } \\
T \\
T, s\end{array}$ \\
\hline
\end{tabular}

somes of hhookeri, the allele $\mathrm{ga}^{-}$in flavens (Fig. 4). The influence of these alleles cannot be seen in a homozygote. In heterozygotes the spores with the allele $g a^{+}$have a better chance for developing a gametophyte and bringing their gametes to fertilization than those with $\mathrm{ga}^{-}$. This leads to the result that the alleles of the same linkage group, which were introduced into the hybrid in the cis-configuration with $\mathrm{ga}^{+}$, will be over-represented in the gametophytes. The corresponding phenotypes will be found more frequently in the progeny than expected on the assumption of undisturbed Mendelian segregations ( $\mathrm{H}$ a r t e 1948, 1953).

$$
\begin{array}{r|}
\text { s flower colour yellow | sulfurea } \\
\text { de position of bracts bent up | down } \\
\text { T translocation point for chromosomes }
\end{array}
$$

hhookeri $1 \cdot 2$ and $3 \cdot 4$

flavens $1 \cdot 4$ and $2 \cdot 3$

ga (f) gene for + gametophyte competitive ability

ga (m) gene for $\sigma^{x}$ gametophyte competitive ability

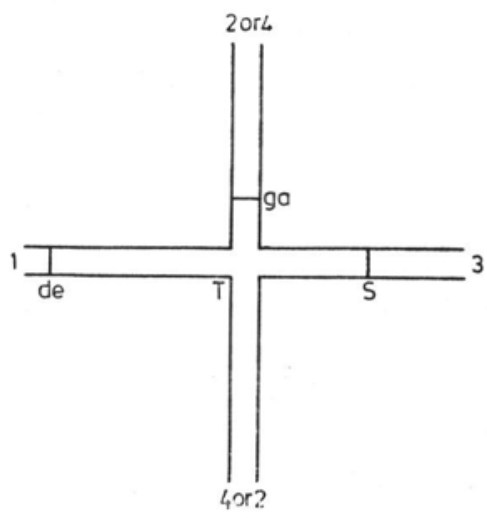

Fig. 4. Oenothera hookeri flavens, map of the first linkage group 
The design of the experimental crosses and back-crosses enabled the testing of the variability of segregation for the test loci $s$, de and $T$ in the progeny. For interpretation of the results, the crossing-over between the markers and the $g a$-locu $u_{\mathrm{S}}$ must be taken into consideration. Let us start with the hypothesis that $\mathrm{ga}^{+}$and $g^{-}$without exceptions determine the fate of a cell as winner or loser in the competition. Then, another gene closely linked to this locus will show a great deficiency of the allele linked to $\mathrm{ga}^{-}$. Only in the exceptional cases when this allele is connected with $\mathrm{ga}^{+}$by crossing-over, it will appear in a functional gamete. Other genes located further away on the chromosome will have a higher cross-over frequency, therefore appear more often with $\mathrm{ga}^{+}$. The other allele, which was originally connected with $\mathrm{ga}^{+}$will be connected with the same frequency with $g a^{-}$and have the disadvantage. By this mechanism, the competition between $\mathrm{ga}^{-}$and $\mathrm{ga}^{+}$will have less effect on genes on the remote ends of the chromosomes.

The translocation point $T$ gives very great deviations from the expectation of random segregation, so this locus must be very near to the site of ga. For the loci $s$ and de, the deviation is less and its variability greater in this order. If we assume a variability of crossing-over-values, which is prooved to exist in Oenothera, the hypothesis of two alleles at the ga-locus is compatible with the results. The test crosses for showing the competition in megaspores and microspores have the same results. It is still not clear, if there exist two closely linked gametophytic genes, one for the regulation of the development of the female and one for the male gametophyte respectively, or if one gene can perform both actions. This gene in the first linkage group controls the development of the microspores and the male gametophytes which have different probabilities of fertilization for their gametes. As it turned out that the interaction between the haploid spores and the diploid heterozygous tissue of the plant from which they originate is the most important factor for the competition of both sexes, a single gene could be responsible for the competition of both megaspores and microspores.

Starting from different assumptions about the situation of the loci on the chromosome arms of a translocation figure, a series of genetic models was developed. Using different values for the frequency of crossing-over between the markers and $g a$, and for the change of probability of fertilization under the influence of the alleles at the $g a$-locus, it was possible to develop a model for a branched linkage-map, correlated to the cytological translocation figure (Fig. 4). The hypotheses of the location of the 3 loci $s$, de and $g a$ in different chromosome arms with the distances $(g a-T)<(s-T)<(d e-T)$ best fits the experimental data, but a linear arrangement with $s$ and de at opposite ends cannot be excluded. The discussion on several developmental models for the gene-action of the $g a$-alleles brought out as the model with the greatest degree of plausi- 
bility the following hypotheses: There exists one locus with two alleles $g \mathrm{a}^{+}$and $g \mathrm{a}^{-}$. Both are active in the diplophase with dominance of $\mathrm{ga}^{+}$, but without visible effects on the phenotype of the sporophyte. Both alleles are active in the spores and gametophytes of both sexes as well. An interaction between the sporophyte and the spores in early stages of their development leads to the disadvantage of spores with $\mathrm{ga}^{-}$on a heterozygous plant containing $\mathrm{ga}^{+}$( $\mathrm{H}$ a r te 1969a).

The series of experiments to elucidate the time of action of $g a$-alleles on the microspores leads to the conclusion that the determination of the chance of fertilization under the influence of $g a$ must be already finished during microspore development in the anthers of a heterozygote. The time when this determination comes to action must be during germination and the early development of the pollen tubes in the most upper part of the style as was shown by certation experiments (H a r t e 1969b, 1972). In other linkage groups genes are found which influence the competition only between the megaspores in the ovules.

From these observations the question arises: what is the cytological basis of the competition in the ovule? Renner (1921) found some pecularities of the development of the embryo sac in Oenothera, but this was not enough to explain the genetical observations. A quantitative analysis of the development of the megaspores and the embryo sac with modern histological and cytochemical methods demonstrated that the competition as it had been established in the genetical experiments, is correlated to phenomena of polarity in the development of the tetrad of megaspores and the embryo sac in the ovule ( $\mathrm{Noher} \mathrm{de} \mathrm{Halac}$ and $\mathrm{H}$ a r te 1975, 1977). In Oe. hookeri and some heterozygotic species and hybrids without competition, that means with normal Mendelian segregation in a genetic experiment, the tetrad of megaspores after meiosis is heteropolar. Only the spore at the micropylar end of the tetrad can develop into an embryo sac. On the contrary, in species and hybrids which show competition in the genetical experiment, the tetrad of megaspores is equipolar. The spores both at the micropylar and the chalazal end of the tetrad can develop into an embryo sac. In these cases the spore with the stronger complex wins the race against the other. In a random segregation at meiosis, this complex will be in $50 \%$ of the cases in the micropylar spore, and in the remaining $50 \%$ of the equipolar tetrads at the chalazal end. In Oe. biennis, which has a very strong competition in the ovules, in $95 \%$ of the tetrads the spores at both ends of the tetrad start to develop into an embryo sac, and in appr. $50 \%$ the chalazal spore will win. That is exactly what is expected on the grounds of the genetic results of crosses with. Oe. biennis as female parent. We can draw the conclusion that at least one of the genes which influence the competition in the ovule act primarily on the developmental process that determines the polarity in the tetrad of megaspores. 
It was shown by Rodkiewicz and his collaborators that the pattern of callose in the ovule and embryo sac of Oenothera is reversed, compared with other types of development of the megaspore (Rodkiewicz 1970 , K u r a n 1972, S n i ézk o 1976). We could confirm this and show in addition, that in those Oenothera-species and hybrids, which have gametophytic competition, there is a variability of the development of the pattern of callose. Newer results demonstrate the genetic basis for the development of polarity in the ovule and the presence of polarizing factors which are independent from the callose pattern ( $\mathrm{S} \mathrm{nie} \dot{\mathrm{z}} \mathrm{k}$ and H a r te 1983a, b).

The genus Oenothera has developed still other possibilities to show us the genetic influence on the gametophytes. In green plants the chloroplasts contain a special type of DNA. Extrakaryotic inheritance was found in Oenothera by Renner (1921) appr. 60 years ago. Later the material basis was localized in the chloroplasts, most probably in the plastid-DNA. In Oenothera several plastomes are known and analyzed by $\mathrm{Stubbe}$ 1959). In some combinations of a given plastome with certain genoms the plastids cannot synthesize chlorophyll. This indicates cooperation between karyotic and extra-karyotic genes in chlorophyll synthesis. But these plastomes have other genes too. In Oenothera suaveolens the complex flavens does not have a pollen inactivating gene and is active in egg cells and pollen tubes as well. Flavens-pollen develops normal pollen tubes and can perform fertilization. S t u b be (1960) found that flavens is inactive in the pollen, when this complex is combined with the plastome of Oe. parviflora. These pollen grains can not germinate. So the plastome of Oenothera must have a gene with at least two alleles that cooperates with one or more karyotic genes in influencing the germination of the male gametophyte ( $\mathrm{Stub}$ b e 1959, 1960, 1964, $\mathrm{S} t \mathrm{u} \mathrm{b}$ be et al. 1978).

Now we can sumamrize the results. In the genus Oenothera several genes are known which regulate the development and function of the gametophyte in both sexes. We still do not know all the genes influencing this part of the generation cycle. For some of the problems there are examples for other species too, as maize, Antirrhinum, Melandrium, but until now only in the genus Oenothera an extensive analysis is performed. The reason is that only the researchers who were interested in the peculiarities of Oenothera-genetics could ask the proper questions and then had the answer from their object. In other genera there is a search for genes with gametophytic action only in the cases of incompatibility and plasmatic male sterility, which is of economic importance. All the other examples were found only as unexpected results in experiments which were planned for other problems. So we do not have any reason to think that genes with gametophytic action are a speciality of Oenothera. We can accept the hypothesis, that the development of the game- 
tophyte is regulated by genes just as it is generally accepted for the sporophyte.

The analysis of gene-action in the development of the gametophytes makes it possible to consider the evolution of the generation cycle of higher plants. We can assume that originally there were forms with two morphologically distinct and physiologically independent generations. These had their own developmental program. So they needed special genes to regulate this. Parallel to the reduction of the gametophyte, which became dependent on nutrition from the sporophyte, some of the genes with gametophytic action could be lost, but some remained and others changed the pattern of action into the cooperation between gametophyte and sporophyte which is found now.

The genus Oenothera is for many biologists a collection of exceptions. But all these specialities in genetics, cytology and development give us the opportunity for an experimental analysis of that part in the development of the plants, the gametophyte, which is difficult to approach in other species. I consider this to be a very fascinating topic in developmental biology.

\section{REFERENCES}

Emerson S., 1939. A preliminary survey of the Oenothera organensis population. Genetics 24: 524.

Emers on S., 1940. Growth of incompatible pollen tubes in Oenothera organensis. Bot. Gaz. 101: 890-911.

$\mathrm{H}$ a r te C., 1948. Zytologisch-genetische Untersuchungen an spaltenden Oenothera-Bastarden. Z. Vererbungsl. 82: 495-640.

$\mathrm{H}$ arte C., 1953. Untersuchungen zur Gonenkonkurrenz und crossing-over bei spaltenden Oenothera-Bastarden. Z. Vererbungsl. 85: 97-117.

$\mathrm{H}$ a r te C., 1958a. Untersuchungen zur Gonenkonkurrenz in der Samenanlage bei Oenothera unter Verwendung der Letalfaktoren als Markierungsgene. I. Die individuelle Komponente der Variabilität. Z. Vererbungsl. 89: 473-496.

H a r te C., 1958b. IL. Die Umweltkomponente der Variabilität. Z. Vererbungsl. 89: 497-507.

Har't e C., 1958c. III. Die genetische Komponente der Vaniabilität. Z. Vererbungsi. 89: 715-728.

Harte C., 1961. Untersuchung über die Gonenkonkurrenz bei Oenothera unter Verwendung der Testloci $f r, s$ und de. Z. Vererbungsl. 92: 142-164.

H a r t e C., 1967. Gonenkonkurrenz. In: Handbuch der Pflanzenphysiologie. Vol. 18. W. Ruhland (ed.). Springer-Verlag, Heidelberg. pp. 447-478.

H a r te C., 1969a. Gonenkonkurrenz bei Oenothera unter dem Einfluß eines gametophytisch wirksamen Gens in der ersten Koppelungsgruppe, sowie ein Modell für die Untersuchung verzweigter Koppelungsgruppen. Theor. Appl. Genet. 39: 163-178.

Harte C., 1969b. Gonenkonkurrenz in der Samenanlage von Oenothera. Theor. Appl. Genet. 39: 241-250. 
Harte C., 1969c. Certationsversuch zur Gonenkonkurrenz unter dem Einfluß des Locus Ga bei Oenothera. Theor. Appl. Genet. 39: 320-325.

H a r te C., 1972. Abhängigkeit der Gonenkonkurrenz im Pollen vom Entwicklungszustand des Griffels bei Oenothera. Theor. Appl. Genet. 42: 215-217.

$\mathrm{H}$ arte C., 1975. Competition in the haploid generation in Oenothera. In: Gamete competition in plants and animals. D. L. Mulcahy (ed.). North-Holland Publishing Company, Amsterdam. pp. 31-41.

Haustein E., 1967. Die selektive Befruchtung. In: Handbuch der Pflanzenphysiologie. Vol. 18. W. Ruhland (ed.). Springer-Verlag, Heidelberg. pp. 479-505.

Kuran H., 1972. Callose localization in the walls of megasporocytes and megaspores in the course of development of monospore embryo sacs. Acta Soc. Bot. Pol. 41: 509-539.

Lew is D., 1948. Structure of the incompatibility gene. I. Spontaneous mutation rate. Heredity 2: 219-236.

Le w is D., 1949. II. Induced mutation rate. Heredity 3: 239-355.

Lewis D. 1951. Structure of the incompatibility gene. II. Types of spontaneous and induced mutation. Heredity 5: 399-414.

Lewis D., Crowe L. K., 1954. IV. Types of mutation in Prunus avium. Heredity 8: $357-364$.

Noher de Halac I., Harte C., 1975. Female gametophyte competition in relation to polarization phenomena during megasporogenesis and development of the embryo sac in the genus Oenothera. In: Gamete competition in plants and animals. D. L. Mulcahy (ed.). North-Holland Publishing Company. Amsterdam. pp. 43-56.

Noher de Halac I., Harte C., 1977. Different patterns of callose wall formation during megasporogenesis in two species of Oenothera (Onagraceae). Plant System. Evol. 127: 23-38.

Oehlkers F., Harte C., 1943. Uber die Aufhebung des Gonen- und Zygotenausfalls bei Oenothera. 1. Teil: Untersuchungen an Oe. cockerelli (F. Oehlkers). 2. Teil: Untersuchungen an Oe. strigosa (C. Harte). Flora N. F. 37: 106-124.

Renner O., 1921. Heterogamie im weiblichen Geschlecht und Embryosackentwicklung bei Oenothera. Z. Bot. 13: 609-621.

Renner O., 1940. Kurze Mitteilungen über Oenothera. IV. Uber die Beziehungen zwischen Heterogamie und Embryosackentwicklung und über diplarrhene Verbindungen. Flora 34: 145-158.

Renner O., Preuss-Herzog G., 1943. Der Weg der Pollenschläuche im Fruchtknoten der Oenothera. Flora 36: 215-222.

Ro dkiewicz B., 1970. Callose in cell walls during megasporogenesis in Angiosperms. Planta 93: 39-47.

S chwemmle J., 1949. Gibt es eine selektive Befrachtung? Biol. Zbl. 68: 195-231.

S chwemmle. J., 1953a. Selektive Befruchtung bei der Oenothera berteriana. Biol. Zbl. 72: 129-146.

Schwemmle J., 1953b. Selektive Befruchtung bei der Oenothera odorata. Biol. Zbl. 72: 405-424.

Steiner E., 1957. Further evidence of an incompatibility allele system in the complex heterozygotes of Oenothera. Amer. J. Bot. 44: 582-585.

Steiner E., 1961a. Incompatibility studies in Oenothera. Z. Vererbungsl. 92: 205-212.

S teiner E., 1961b. Incompatibility in the complex heterozygotes of Oenothera. Genetics 46: 301-315.

Stubbe W., 1959. Genetische Analyse des Zusammenwirkens von Genom und Plastom bei Oenothera. Z. Vererbungsl. 90: 288-298. 
Stubbe W., 1960. Untersuchungen zur genetischen Analyse des Plastoms von Oenothera. Z. Bot. 48: 191-218.

$\mathrm{Stubbe}$ W., 1964. The role of the plastome in evolution of the genus Oenothera Genetica 35: 38-43.

Stubbe W., Pietsch W., Kowallik K. W., 1978. Cytologische Untersuchungen über väterliche Plastidenvererbung und plastom-abhängige Degeneration der Samenanlagen bei einem Oenothera-Bastard. Biol. Zbl. 97: 39-52.

Snieżko R., 1976. Distribution of polysaccharids during megasporogenesis in Onagraceae. Ann. U. M. C. S. 31: 183-191.

Snieżko R., Harte C., 1983a. Polarity and competition between megaspores in the ovule of Oenothera hybrids. Plant System. Evol. (in print).

Snieżko R., Harte C., 1983b. Callose pattern and polarization phenomena in the ovules in the $\mathrm{F}_{2}$-hybrids between Oe. hookeri and suaveolens (in preparation).

Kontrola genetyczna rozwoju pokolenia haploidalnego Oenothera

Streszczenie

Pokolenie haploidalne roślin wyższych powinno być traktowane jako odrębna całość. Potrzebne są specjalne warunki doświadczalne do badania procesów rozwojowych męskiego i żeńskiego gametofitu w okresie między mejozą i zapłodnieniem. Wyniki badań Oenothera wskazują na istnienie genów, których działanie można uznać za wpływające na konkurencję między mejosporami lub między gametofitami, albo na wpływające na interakcje między różnymi osobnikami (niezgodność: gametofit-gametofit lub gametofit-sporofit). Rozwój pokolenia gametofitowego regulują geny. Niektóre z tych genów są aktywne tylko w tej fazie cyklu życiowego. 